\title{
Filtration of particles from suspension by the American oyster Crassostrea virginica
}

Dexter S. Haven

Virginia Institute of Marine Science

Reinaldo Morales-Alamo

Virginia Institute of Marine Science

Follow this and additional works at: https://scholarworks.wm.edu/vimsarticles

Part of the Aquaculture and Fisheries Commons

\section{Recommended Citation}

Haven, Dexter S. and Morales-Alamo, Reinaldo, "Filtration of particles from suspension by the American oyster Crassostrea virginica" (1970). VIMS Articles. 1805.

https://scholarworks.wm.edu/vimsarticles/1805

This Article is brought to you for free and open access by W\&M ScholarWorks. It has been accepted for inclusion in VIMS Articles by an authorized administrator of W\&M ScholarWorks. For more information, please contact scholarworks@wm.edu. 
Reference : Biol. Bull., 139: 248-264. (October, 1970)

\title{
FILTRATION OF PARTICLES FROM SUSPENSION BY THE AMERICAN OYSTER CRASSOSTREA VIRGINICA ${ }^{1}$
}

\author{
DEXTER S. HAVEN AND REINALDO MORALES-ALAMO \\ Virginia Institute of Marine Science, Gloncester Point, Virginia 23062
}

The oyster Crassostrea virginica is a suspension feeder which retains suspended particulate material on its gills. These are lamellar and composed of rows of filaments in groups that constitute folds (plicae) in the lamellar surface (Nelson, 1960). Water is pumped through small interfilamentary openings (ostia) by the action of cilia on the filaments. The actual manner in which particles are retained on the gills is not completely understood (Jorgensen, 1966). Suggested mechanisms include entrapment in mucus, straining action of large latero-frontal cilia, and limitation of passage through the gills by the size of the interfilamentary ostia.

Two methods have been commonly used to study particle filtration by bivalves. One involves channeling water into and from shell cavities with devices which collect all water flowing through the gills (Galtsoff, 1928; Loosanoff and Engle, 1947; Tammes and Dral, 1955). These studies have been criticized because oysters may not behave normally when subjected to the stress of the collecting device. The second involves measurements of rates at which undisturbed lamellibranchs clear particles in standing water. This latter method has been used extensively by many workers in recent years (Jørgensen, 1949, 1960; Ballantine and Morton, 1956; Chipman and Hopkins, 1954: Jorgensen and Goldberg, 1953; Willemsen, 1952). Objections to studies in standing water are that previously filtered material may be resuspended and refiltered (recycled) and also that particle concentrations will change with time. With only several exceptions, as exemplified by the work of Loosanoff and Engle (1947), particle density was measured indirectly by techniques such as isotope labeling, per cent light transmission, etc. Results of these studies differ widely in respect to the efficiency at which various size particles are filtered from suspension. No one has correlated the results of these investigations with the structures and mechanisms which determine them (Jørgensen, 1966).

The purpose of this investigation was to establish more precisely the size of the smaller particles removed from suspension by the American oyster Crassostrea virginica and the efficiency of removal and to relate our results to the most probable mechanism involved.

\section{Materials ANd Methons}

\section{Apparatus and materials}

The basic design of the study was to hold oysters in troughs of flowing water and to measure differences in numbers of particles entering and leaving the system. Differences were attributed to filtration by the animals. The experimental ap-

1 Contribution No. 356 from the Virginia Institute of Marine Science. This research was supported by U. S. Atomic Energy Commission Grant No. AT-(40-1)-2789. 


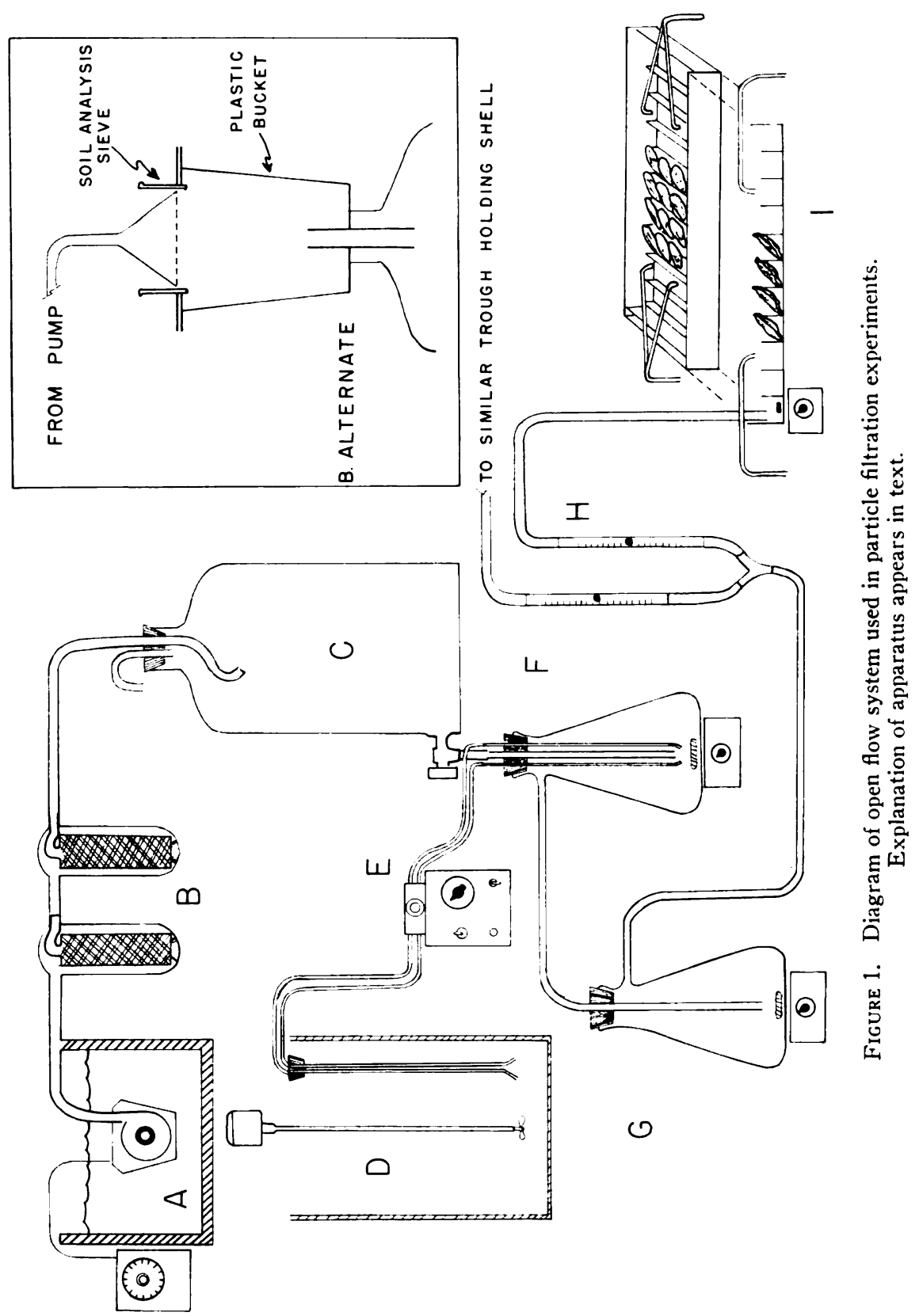


proach of our study differed from previous studies in several respects. Particle filtration was studied simultaneously over a continuous spectrum of sizes ranging from about $1.0 \mu$ to $12.0 \mu$, and direct measurements and counts of the particles involved were made. Water flowed continuously over the oysters under conditions approaching those of the natural environment. This also served to avoid recycling. Filtration activity was not measured instantaneously but covered a period of approximately $12 \mathrm{~min}$.

The experiments were conducted at the Virginia Institute of Marine Science. Gloucester Point. Virginia. Preliminary studies began in 1964 and 1965, but most data were obtained during 1966 and 1967.

Water for all studies was pumped through plastic pipes from a source $0.5 \mathrm{~m}$ above the bottom, $90 \mathrm{~m}$ offshore in the York River, to a constantly overflowing overhead trough in the laboratory. Water flow in 1966 experiments was 1.01 $1 / \mathrm{min}$; in 1967 , flows were regulated to range from 0.19 to $1.01 \mathrm{l} / \mathrm{min}$.

Data were collected using a system having continuous water flow over the oysters and controls (single oyster shells). Particle removal was studied in respect to 1) the natural particle complement of York River water (in one series of experiments) and 2) kaolinite clay particles added to filtered York River water. Kaolinite (American Petroleum Institute standard no. 7, Bath, South Carolina) with a density of 2.6 was similar to the mineral components of suspended matter in the York River (Nelson, 1963).

The apparatus used is shown in Figure 1. Water was pumped intermittently from an overhead trough (A) through two spool-wound yarn depth filters (porosity of $20 \mu$ and $1 \mu$, respectively) in series (B) into a 13-gal polyethylene carboy (C). An alternate filtration system (B Alternate) was used in series with river water without added materials. In these experiments a standard soil analysis sieve with mesh size of $44 \mu$ was substituted for the depth filters. Passage through the soil analysis sieve did not appreciably change quantity of suspended solicls since it had been found previously that $97 \%$ by weight of the suspended material in the York River passes through a $44 \mu$ sieve (Haven and Morales-Alamo, 1968). The carboy served to maintain a relatively constant water head and to enhance dissipation of air bubbles.

Kaolinite particles added to the flowing water were maintained in suspension in an acrylic tank (D) with an electric stirrer. From this source they were metered with a peristaltic pump (Harvard Apparatus Co., Dover, Massachusetts) into a 4.000-cc mixing flask ( $F)$. A magnetic stirrer mixed the suspensions with the filtered water and a second $4,000-\mathrm{ml}$ flask $(G)$ in series with the first enhanced homogeneity.

The mixture passed through flow meters $(\mathrm{H})$ into two identical acrylic plastic experimental troughs (I) holding live oysters and oyster shells. respectively: troughs were $47 \mathrm{~cm}$ long by $13 \mathrm{~cm}$ wide and $6 \mathrm{~cm}$ high. A small magnetic mixing bar at the head of each trough under the inflowing hose further mixed the inflowing suspension. Three oysters (or shells) were placed side by side in each of four successive compartments. Twelve oysters were used in all studies except several in 1967 which used 24. Water depth above oysters and shells was approximately $2 \mathrm{~cm}$.

Oysters came from an area free of known oyster diseases (Horsehead Rock) in the James River, Virginia. They were about 2 years old and averaged $50 \mathrm{~mm}$ in 
height with a mean wet meat weight of $4.8 \mathrm{~g}$. To minimize possibility of particle recycling, flows and oyster numbers were chosen so that flow exceeded the theoretical pumping capacity of the oysters. Calculations showed that each oyster received a flow of $1.05 \mathrm{l} / \mathrm{hr}$ per gram of wet meat weight. Jorgensen (1966) summarized data showing that adult oysters may pump through their gills from 0.5 to $0.81 / \mathrm{hr}$ per gram of wet meat weight.

Oysters and shells were scrubbed, rinsed, and immediately placed in experimental troughs enclosed in a large, darkened box.

Total solids were measured by filtration through $0.45 \mu$ membrane filters. Salinities and temperatures were monitored daily during the experimental periods with a stem hydrometer and a Foxboro recording thermometer, respectively. During 1966, studies extended from 24 June to 14 October, during which period salinities ranged from 18.0 to $24.1 \%$ and temperatures from 17.9 to $28.0^{\circ} \mathrm{C}$. In 1967, experiments were conducted from 10 May to 12 June, with temperatures ranging from 14.2 to $23.4^{\circ} \mathrm{C}$ and salinities from 19.0 to $20.2 \%$.

\section{Collection of samples}

Samples of water for particle size analysis were collected simultaneously from two pairs of 3-mm I.D. glass tubes which siphoned water continuously from the troughs halfway between the water surface and the top of the compartmental baffles (Fig. 1). One pair of tubes was located over the compartment immediately preceding the oysters (or shells), a second pair over an empty compartment at the outlet. Samples were not collected until oysters were actively pumping and producing faeces or pseudofaeces, a period ranging from $\frac{1}{2}$ to $2 \mathrm{hr}$. Faeces or pseudofaeces produced by the oysters settled to the bottom of the troughs without contributing to the particle load flowing from the system. Each sample to be analyzed for particle size was obtained by combining five subsamples, each of which took about $30 \mathrm{sec}$ to collect and was obtained at 3-min intervals over a 12-min period. Consequently, each sample represented oyster activity over a 12-min interval.

In many experiments it was necessary to dilute samples to retard flocculation and reduce inaccurate counts resulting from coincident passage of particles through the tube orifice of the Coulter Counter. York River water, filtered twice through $0.45 \mu$ membrane filters, was used as dilutant. Subsamples collected from the troughs were diluted immediately by pouring into a flask containing a predetermined volume of dilutant. Dilution factors ranged between 1.9 and 3.6, depending on particle concentrations flowing through the troughs. After collection, samples were held at $26^{\circ} \mathrm{C}$ in a constant temperature water bath until counted since it was earlier found that changes in sample temperature affected the counts recorded by the Coulter Counter.

\section{Coulter Counter and analysis of samples}

Particles in the water samples were measured and counted using a Model B Coulter Electronic Particle Counter (Coulter Electronics, Inc., Franklin Park, Illinois). The counter principle is based on particles suspended in an electrolyte being forced through a small orifice between two electrodes through which an electric current path has been established; each particle displaces electrolyte in 
the orifice essentially equal to its volume and creates a change in current resistance proportional to this volume (Kubitschek, 1960; Sheldon and Parsons, 1967). The counter does not measure linear dimension, and particle diameter is calculated from the displaced volume and represents the diameter of a sphere laving the same volume as the particle. Particle counts are recorded on a decade counter.

Cumulative particle counts made at increasing consecutive particle size settings were processed through an IBM 360 computer. Counts were corrected for coincident passage through the orifice, for background count in the dilutant water,

TABLE: I

\begin{tabular}{|c|c|c|c|}
\hline \multirow{2}{*}{ Size fraction $\underset{(\mu)}{(\mu)}$} & \multirow{2}{*}{ No. replications } & \multicolumn{2}{|c|}{$\begin{array}{c}\text { No. of particles } \\
\text { (millions) }\end{array}$} \\
\hline & & Mean & Range \\
\hline \multicolumn{4}{|c|}{ Natural particles } \\
\hline $\begin{array}{r}1.00-1.99 \\
2.00-2.99 \\
3.00-3.99 \\
4.00-4.99 \\
5.00-5.99 \\
6.00-6.99 \\
7.00-7.99 \\
9.00-9.99 \\
11.00-11.99\end{array}$ & $\begin{array}{l}3 \\
3 \\
6 \\
6 \\
6 \\
5 \\
4 \\
3 \\
3\end{array}$ & $\begin{array}{r}1001.4 \\
103.2 \\
33.3 \\
10.9 \\
5.5 \\
2.3 \\
1.1 \\
0.3 \\
0.1\end{array}$ & $\begin{array}{c}790.4-1230.6 \\
77.3-1.31 .0 \\
20.4-48.3 \\
6.4-14.0 \\
4.2-7.6 \\
1.6-2.8 \\
1.1-1.3 \\
0.3-0.4 \\
0.1-0.1\end{array}$ \\
\hline \multicolumn{4}{|c|}{ Kaolinite particles } \\
\hline $\begin{array}{l}1.00-1.99 \\
2.00-2.99 \\
3.00-4.99 \\
5.00-6.99\end{array}$ & $\begin{array}{l}34 \\
34 \\
34 \\
12\end{array}$ & $\begin{array}{r}921.2 \\
.25 .8 \\
59.2 \\
8.9\end{array}$ & $\begin{array}{c}391.7-1756.0 \\
65.1-492.1 \\
16.2-118.0 \\
4.5-16.7\end{array}$ \\
\hline
\end{tabular}

and for dilution, and were then converted to differential counts. The latter were subsequently converted to total volume of all particles in the size interval. Size intervals were $1.0 \mu$ in most instances; however, on several occasions intervals ranging from 0.1 to $0.5 \mu$ were used for sizes near $1.0 \mu$. In several instances intervals of $2.0 \mu$ were used for sizes larger than $5.0 \mu$. Efficiency of removal of particles is expressed as per cent difference in numbers of particles of a size interval between the inflowing and outflowing water samples.

Data collected in preliminary studies conducted in 1964 and 1965 were subject to excessive variations in the control data and are presented only as a supplement to data obtained in 1966 and 1967 . Later modifications elininated this problem (see Methods).

The data on per cent removed were compared by analysis of variance after being transformed into degrees using the arcsin percentage transformation. Further 
analysis was made using Scheffé's multiple mean comparison method (Guenther, 1964). Data are presented graphically in terms of the point and $95 \%$ interval estimate of the mean, $\bar{x} \pm S_{\bar{x}} t_{0.05}$, where $\bar{x}=$ mean, $S_{\bar{x}}=$ sample standard error and $t_{0.0 .5}=$ the $5 \%$ level of student's $t$ distribution (Snedecor, 1956).

\section{RESUlts}

Individual experiments with kaolinite and natural particles showed a consistent pattern. There was a sharp increase in per cent of particles removed as particle size increased from 1.0 to between 2.0 and $4.0 \mu$. At larger sizes the per cent removed leveled off with no indication of further increase in efficiency.

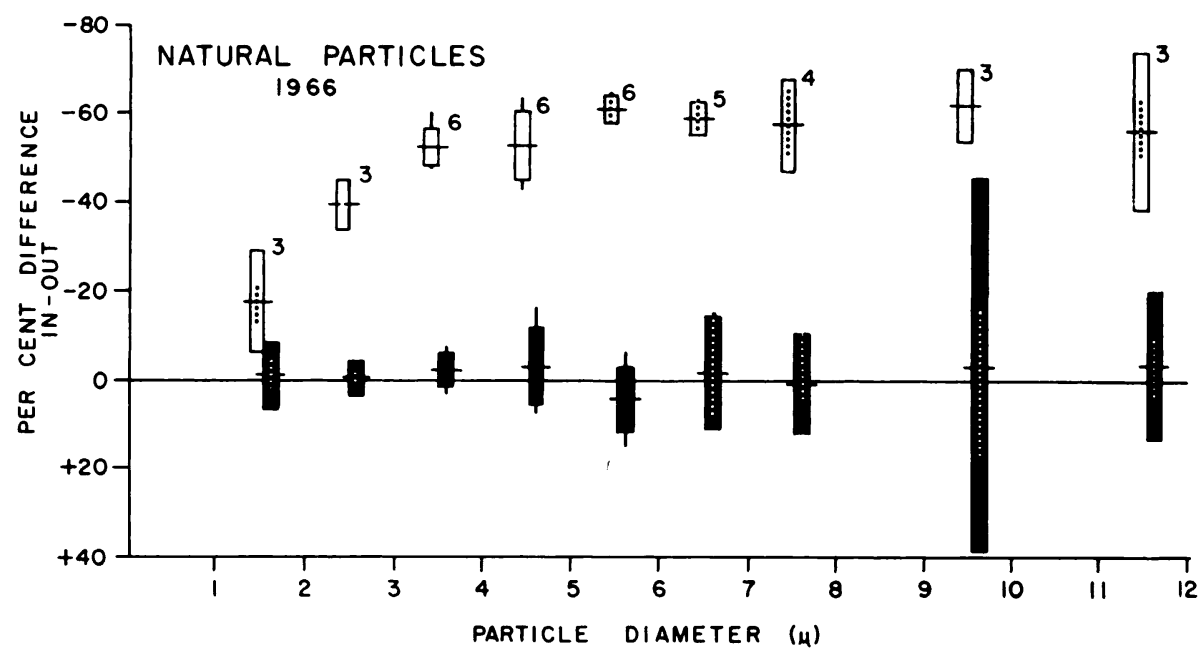

Figure 2. Mean per cent difference between particle numbers in water entering and water leaving experimental troughs for separate size fractions in 1966 natural particles experiments, plotted at mid-point of size interval ; open bars = oysters, solid bars = shells; horizontal line = mean, vertical line $=$ range, bar $=$ interval estimate $\left(\bar{i} \pm S_{\bar{r}} t_{0.05}\right)$. Figures over bars indicate number of replications.

Variations were present between individual experiments, especially in those using kaolinite particles, but the general pattern described above appeared condifferences in the filtration activity of the oysters at the time a particular experiment was conducted. Insofar as temperature is concerned, Loosanoff (1958) observed no significant change in pumping rate of oysters between 16 and $28^{\circ} \mathrm{C}$. In the absence of any observed relation for these three parameters, data for particle sistently in every experiment. These variations could not be correlated to differences in temperature, salinity or particle concentration and probably resulted from removal were combined for similar size intervals. Results of studies made at size intervals different from those included above are reported separately. During most studies, oysters produced faecal strings and pseudofaeces, indicating filtration of particles from suspension and ingestion of some. 
Filtration under flow of $1.01 \mathrm{l} / \mathrm{min}$ using 12 oysters

Filtration of natural particles was studied in 1966 using 12 oysters and a flow of $1.011 / \mathrm{min}$. A total of six studies was combined into a composite curve at intervals of $1.0 \mu$ (Fig. 2 ).

Particles in the undiluted water entering the trough were by far the most abundant in the 1.0 to $2.0 \mu$ size range where an average of over 1 billion per liter was measured. Numbers decreased rapidly with size and only 70,000 per liter were

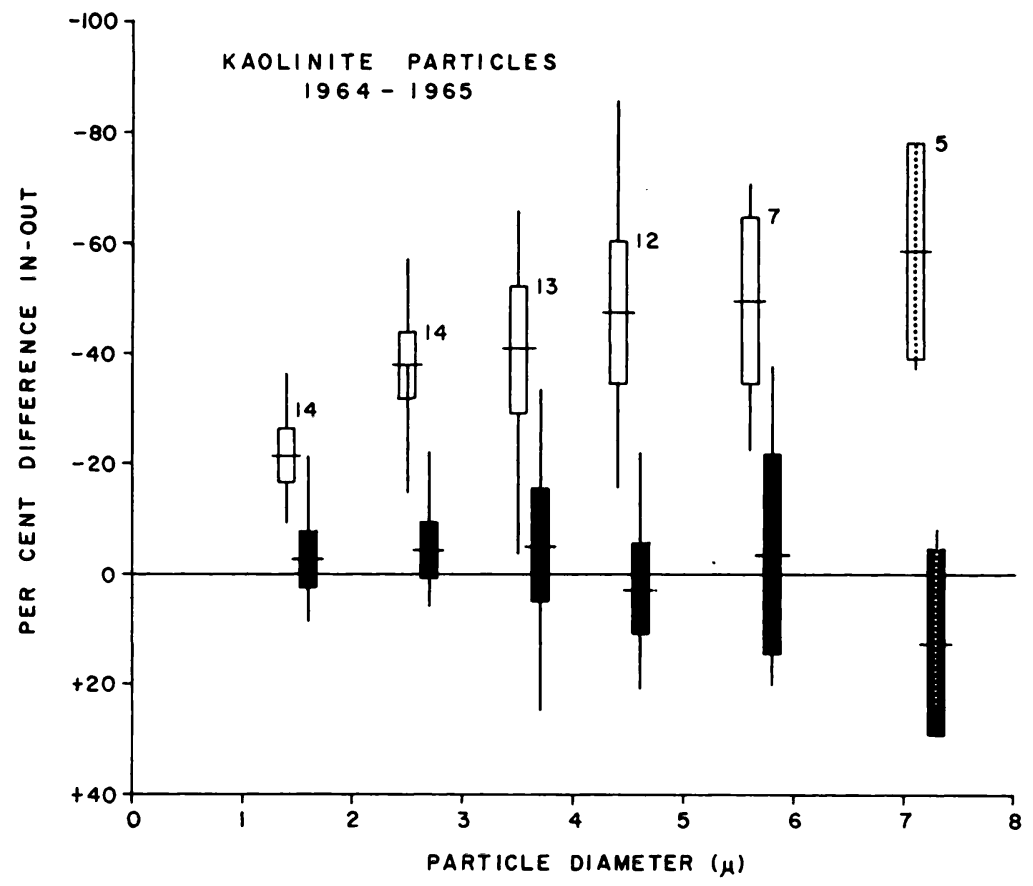

FigURE 3. Mean per cent difference between particle numbers in water entering and water leaving experimental troughs for separate size fractions in 1964-1965 kaolinite particles experiments; open bars $=$ oysters, solid bars = shells; horizontal line $=$ mean, vertical line $=$ range, bar $=$ interval estimate $\left(\bar{x} \pm S_{\bar{x}} t_{0.06}\right)$. Figures over bars indicate number of replications.

measured in the 12.0 to $13.0 \mu$ size range (Table I). Total solids were not consistently measured; however, during July and August 1966 in the York River they ranged from 4.7 to $29.0 \mathrm{mg} / \mathrm{l}$, with a mean of about $10.0 \mathrm{mg} / 1$ (Haven and Morales-Alamo, 1966a).

Oysters removed a mean of $18 \%$ of the particles between 1 and $2 \mu$. Average removal increased to $53 \%$ between 3.0 and $4.0 \mu$. Above this size, there was no evidence of further differences in efficiency of removal up to $12.0 \mu$. Mean per cent differences between inflow and outflow in the controls were close to zero with a small variance for most size intervals. There was no evidence of a difference among these means. 
Two separate studies conducted in August 1966 using natural particles with 12 oysters and a flow of $1.01 \mathrm{l} / \mathrm{min}$ included size intervals under $1 \mu$. In the first, oysters removed $34.8 \%$ of the particles between 0.8 and $0.9 \mu$ and $37.8 \%$ of the particles between 0.9 and $1.0 \mu$. The second experiment showed a removal of $28.5 \%$ for particles between 0.9 and $1.0 \mu$.

Data on filtration of kaolinite particles obtained during preliminary studies conducted in 1964 and 1965 showed a similar pattern of removal with increase in

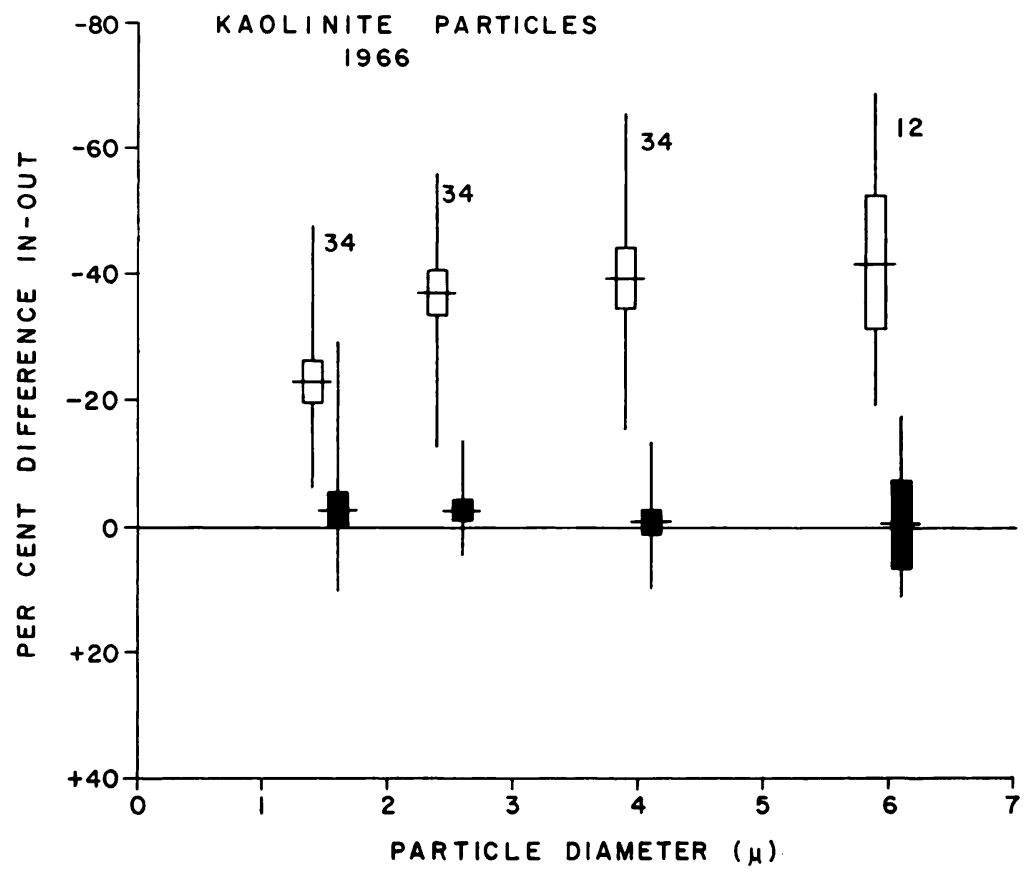

FIgURE 4. Mean per cent difference between particle numbers in water entering and water leaving experimental troughs for separate size fractions in 1966 kaolinite particles experiments; open bars $=$ oysters, solid bars $=$ shells; horizontal line $=$ mean, vertical line $=$ range, bar $=$ interval estimate $\left(\bar{x} \pm S_{\bar{x}} t_{0.05}\right)$. Figures over bars indicate number of replications.

particle size (Fig. 3). Removal efficiency increased from $21 \%$ between 1.0 and $2.0 \mu$ to $38 \%$ between 2.0 to $3.0 \mu$; there was no evidence of further change in efficiency at larger sizes. The values recorded in these data are not considered reliable because of the excessive variation observed in the data but are included here only to illustrate the recurrence of a platean in removal efficiency at particle sizes larger than $3 \mu$.

Data on filtration of kaolinite particles in 1966 were obtained by combining 34 separate studies using a flow of $1.01 \mathrm{l} / \mathrm{min}$ and 12 oysters. Particles over $7.0 \mu$ in the diluted samples were too few for precise counts and were not included in the analysis.

Particles in the undiluted inflowing water were most numerous in the 1.0 to $2.0 \mu$ size range where they averaged 921 million per liter. Particle number decreased to 8.9 million between 5.0 and $6.0 \mu$ (Table I). 
Removal of particles between 1.0 and $2.0 \mu$ averaged $24 \%$ (Fig. 4). This increased to $37 \%$ for $2.0-3.0 \mu$ particles and reached $42 \%$ between 5.0 and $7.0 \mu$. There was no evidence of a significant difference in mean per cent removed among the three particle size fractions included between 2.0 and $7.0 \mu$. In the controls, mean differences in particle counts between inflow and outflow were close to zero, with only small variances for all size intervals. As in studies with natural

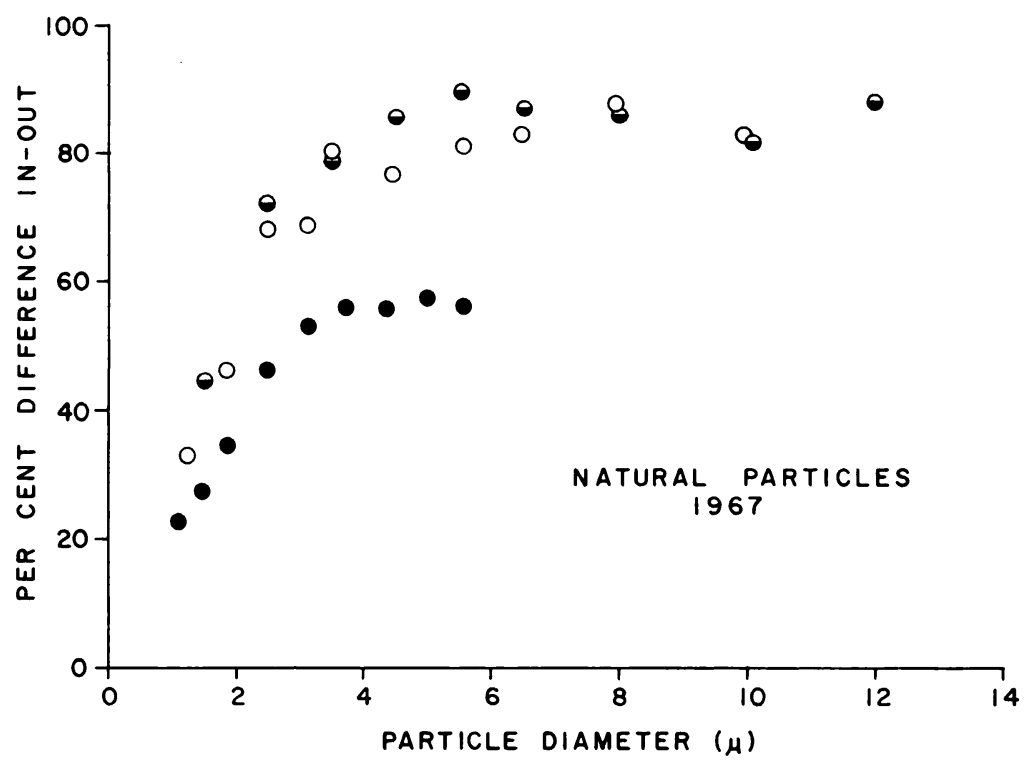

FigURE 5. Mean per cent difference between particle number in water entering and water leaving experimental trough with oysters for separate size fractions in 1967 natural particles experiments, plotted at mid-point of size interval; solid circles $=12$ oysters, flow of $1.01 \mathrm{l} / \mathrm{min}$; open circles $=12$ oysters, flow of $0.19-0.42 \mathrm{l} / \mathrm{min}$; half-filled circles $=24$ oysters, flow of $0.83-$ $1.01 \mathrm{l} / \mathrm{min}$.

particles, there was variation between rates of removal at various particle sizes. However, most of the studies fell within relatively narrow limits.

Two of the experiments with kaolinite particles conducted in August 1966 included counts made at intervals smaller than $1.0 \mu$. These showed an average per cent removal of $32.7 \%$ for particles between 1.1 and $1.5 \mu, 43.9 \%$ for particles between 1.5 and $2.0 \mu$, and $54.2 \%$ for particles between 2.0 and $2.5 \mu$.

\section{Filtration under variable flow and oyster number}

It was possible that the basic pattern of particle removal for all preceding data was a direct result of the particular experimental conditions used, i.e., a flow of $1.01 \mathrm{l} / \mathrm{min}$ and 12 oysters. To test this possibility, experiments with natural particles were conducted in May 1967 at various flow rates and with 12 or 24 oysters. 
Per cent removal using the standard $1.01 \mathrm{l} / \mathrm{min}$ flow with 12 oysters increased from $23 \%$ for particles between 1.0 and $2.0 \mu$ to $56 \%$ between 3.0 and $4.0 \mu$. No change in per cent removed was evident for sizes above $4.0 \mu$ (Fig. 5 , solid circles). These data were almost identical to data collected in the 1966 experiments. Seven experiments were conducted at flows of $1.01 \mathrm{l} / \mathrm{min}$ but with 24 oysters. Doubling oyster number displaced the entire curve upward. The basic pattern, however, remained the same (Fig. 5, half-filled circles), with efficiency increasing

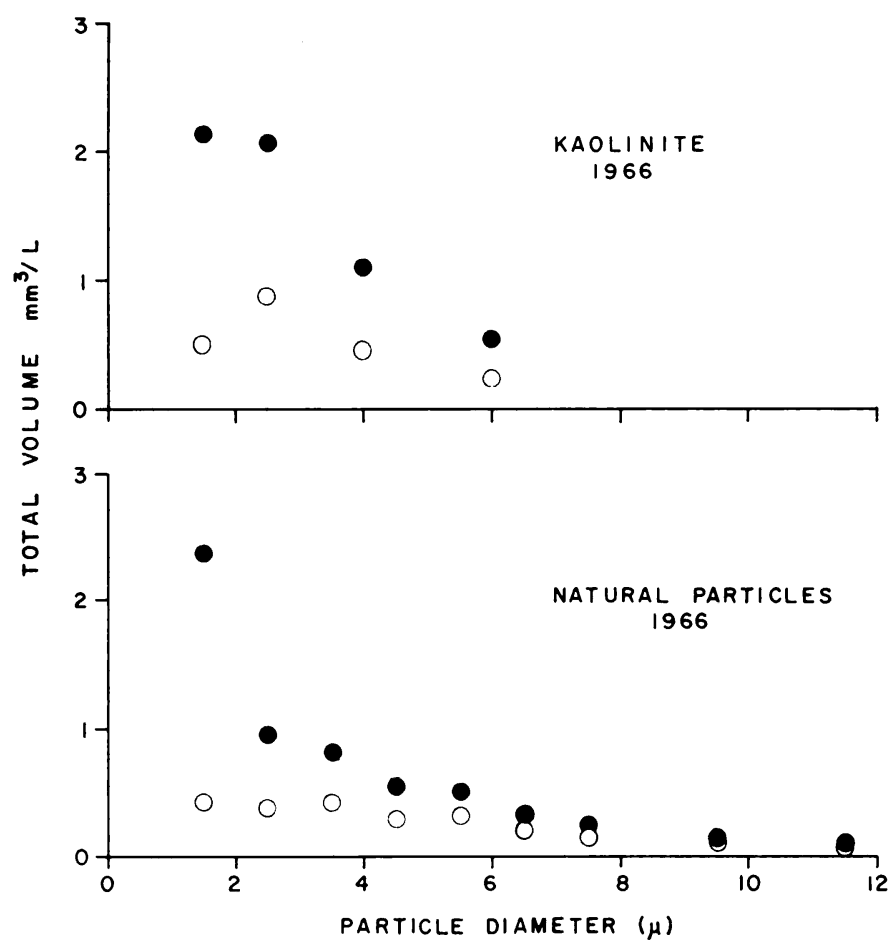

Figure 6. Mean total volume of particles in the different size fractions entering and leaving experimental troughs with oysters in 1966 kaolinite and natural particles experiments, plotted at mid-point of size interval ; closed circle $=$ entering, open circle $=$ leaving.

in the 1.0 to $4.0 \mu$ range and then leveling off at about $88 \%$. In effect, doubling oyster number nearly doubled rates of removal. A reduction in flow but with 12 oysters had nearly the same effect as doubling oyster number and the basic pattern was still evident (Fig. 5, open circles).

\section{Particle removal in terms of volume}

It was shown previously that natural particles were numerically most abundant between 1.0 and $2.0 \mu$ and decreased to much lower levels between 11.0 and $12.0 \mu$. A similar relationship was found when particle numbers were converted to volumes (Fig. 6). Mean total volume for particles between 1.0 and $2.0 \mu$ entering 
the system was about 2.5 times greater than in either of the next two larger size fractions and decreased significantly with particle size in the size range included. A test on the slope of the regression of mean total volume removed on particle size showed that it was significantly different from $0(P<0.05)$. Therefore, volume removed decreased with increase in particle size $(r=0.971)$. The mean volume removed by oysters between 1.0 and $2.0 \mu$ was $0.425 \mathrm{~mm}^{3}$, but only $0.066 \mathrm{~mm}^{3}$

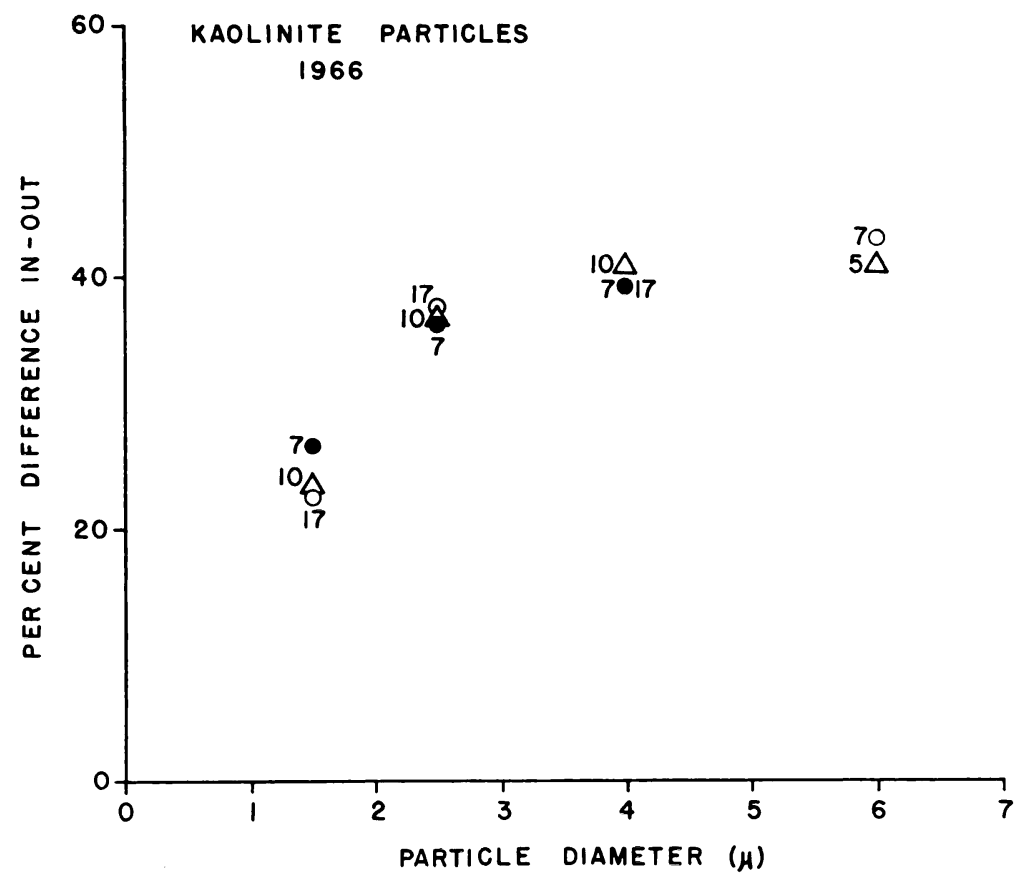

Figure 7. Mean per cent difference between particle numbers in water entering and water leaving experimental troughs for separate size fractions in 1966 kaolinite experiments. Data grouped into three intervals representing low, moderate and high particle concentrations in inflowing water $;$ solid circles $=5.91-10.10 \mathrm{mg} / 1$; open circles $=11.40-19.60 \mathrm{mg} / 1$; open triangles $=20.34-37.66 \mathrm{mg} / \mathrm{l}$. Figures represent number of replications.

between 11.0 and $12.0 \mu$. The combined volume removed between 1.0 and $4.0 \mu$ represented $52.0 \%$ of the total removed between 1.0 and $12.0 \mu$; that removed between 7.0 and $12.0 \mu$ represented much less, being $13.5 \%$ of the total. The 4.0 to $7.0 \mu$ fraction represented $34.5 \%$ of the total.

Conversion of kaolinite particle counts to volume also showed a greater mean total volume of particles between 1.0 and $2.0 \mu$ than of any of the other size fractions entering the system (Fig. 6). Volumes plotted at the mid-points for the 3.0-5.0 and 5.0-7.0 $\mu$ intervals are one-half of the total volumes in the $2.0 \mu$ intervals. That is, the value plotted represents mean removal rates for a $1.0 \mu$ interval.

The data for volumes of kaolinite particles removed were distributed differently than those for natural particles. Although a relatively high correlation coefficient 
of $r=0.751$ was obtained, further analysis showed no evidence that the regression slope of mean total volume on particle size was signiticantly different from 0 $(P>0.05)$. Therefore, the data do not show that volume removed decreased with increase of particle size. They do show, however, that as much volume between 1.0 and $2.0 \mu$ was removed as of any other size fraction.

The preceding results show that volumes of suspended material removed by oysters in the vicinity of $1.0-3.0 \mu$ are at least as great as those in larger size intervals measured when considered in terms of the total volume rather than in terms of the efficiency with which oysters remove then.

Volume data from individual experiments with kaolinite particles, conducted in 1966 , were used to illustrate the absence of a relation between concentration of particles entering the system, expressed as $\mathrm{mg} / \mathrm{l}$, and per cent of the particles removed. For this purpose, the data were converted into $\mathrm{mg} / \mathrm{l}$ by multiplying total volume of all particles in the size spectrum included in each experiment by 2.6, the approximate density value for kaolinite. These data were then grouped into three intervals representing low, moderate and high concentrations. These were, respectively, 5.91-10.10, 11.40-19.60 and 20.34-37.66 mg/l (Fig. 7).

Results showed that, within the size and volume limits studied, the quantity of material present in the inflowing water did not affect the per cent of particles removed at any of the size intervals measured or the shape of the curve for per cent removed $v s$. particle size.

\section{Discussion}

Jørgensen (1960) states that results obtained by different investigators often vary or even disagree and that quantitative data on feeding in lamellibranchs would be of greater value if they can be shown to have been derived from experiments on undisturbed animals. We consider that our experimental technique approached the undisturbed conditions of the natural environment.

Other workers have found a relation similar to that shown by our data between particle size and per cent removal for $C$. virginica while the data of others disagree. Jørgensen and Goldberg (1953) found that graphite particles of sizes down to a few microns were effectively retained by $C$. rirginica and that $80 \%$ of the 1.0 to $2.0 \mu$ particles passed through the gills. Loosanoff and Engle (1947) showed that cells of the flagellate Euglena $60 \mu$ in length easily passed through the gills of C. virginica and sometimes only $15 \%$ was removed from suspension. In the $5.0 \mu$ size they found oysters retained 0 to $85 \%$ of the Chlorella sp. cells. They concluded that little correlation existed between size of the microorganisms and per cent removed by the gills. It is possible that differences in experimental techniques and in materials being filtered may adequately account for differing results.

Our experiments show a well defined pattern of particle removal when results are expressed in terms of per cent removal. Consistently and regardless of experimental conditions, oysters removed particles in the size range of 1.0 to $2.0 \mu$ with less than half the efficiency of the larger particles. Efficiency increased with particle size up to $3.0-4.0 \mu$ for natural particles and to $2.0-3.0 \mu$ for kaolinite and then leveled off, with no evidence of a further change in efficiency. Minimum size of natural particles removed was between 0.8 and $0.9 \mu$, when $34.8 \%$ of the available particles were removed. 
The increased efficiency of particle removal with an increase in particle size was not unique to flows of $1.01 \mathrm{l} / \mathrm{min}$ and 12 oysters. Doubling oyster number at $1.01 \mathrm{1} / \mathrm{min}$ had the effect of displacing the entire curve upward, $24 \%$ in the 1.0 $2.0 \mu$ range and from 34 to $42 \%$ in the larger size range. The inflection point on all curves, however, was still in the 3.0-4.0 $\mu$ range. A similar inflection point was also demonstrated when flows were reduced.

The percentage value at which the curves level off in our experiments is interpreted as representing the relation between the quantity of water filtered through the oysters' gills and the total volume of water flowing through the trough. Where the curve levels off at a removal of $60 \%$, it is suggested that oysters were only pumping through their gills about $60 \%$ of the water flowing over then. This interpretation is supported by the fact that the curve was displaced upward when flows were decreased or oyster number increased without any changes in the nature of the curve itself. Furthermore, it was outlined earlier that oysters in our study were receiving $1.05 \mathrm{l} / \mathrm{hr}$ per gram of tissue. This is in excess of the 0.5 to $0.8 \mathrm{l} / \mathrm{hr}$ per gram of tissue pumping rates of achlt oysters summarized by Jorgensen (1966). Leveling off of the curves, therefore, inclicates that all particles larger than the size of which the inflection point occurs are being completely filtered out of the water pumped through the gills.

The constancy in location of the inflection point in the curves suggests that it represents the smallest particle size that oysters can retain with complete efficiency. Jørgensen (1966) stated that such a sharp size limit between retainable and nonretainable particles is an indication that it is particle size and therefore the porosity of a filter that is responsible for retention. He also stated that the critical size for particle retention in Crassostrca zirginica corresponds to the distance between adjacent latero-frontal cilia on a filament, which according to Atkins (1938) varies between 1.5 and $3.7 \mu$. This range coincicles with the range of particle sizes at which the inflection point appears on our curves. This correspondence reinforces the suggestion that the distance between adjacent latero-frontal cilia is the factor that determines the smallest particle size that can be completely retained by the oyster gill.

It is difficult to reconcile the preceding mechanism of removal with the observed quantity of material removed in the 0.8 to $3.0 \mu$ range in our experiments. Several possibilities exist: (1) The Coulter Counter essentially measures volume of particles and results are expressed in terms of the liameter of spheres of equal volume. It would be illogical to assume that the smaller particles would be round since particles in the 0.8 to $3.0 \mu$ size range might inclucle lenticular clay particles, ovoid dinoflagellates, rod-shaped bacteria, $c t c$. It is possible that the orientation of the long axis of these irregularly shaped particles as they strike the filtering mechanism results in retention of a fraction of their numbers. (2) Smaller particles may be trapped in with the larger ones, as suggested by Smith (1958), or adhere in some way to mucus on the gills. (3) Passage of particles through the interplicar spaces may stimulate blood to be pumped into the vascular tissue surrounding the ostia resulting in partial closure of these openings (Elsey, 1935). (4) The gill musculature may exert some regulation on the porosity of the gill filter by adjusting the width of the ostia (Jyrgensen, 1966). 
The mucous sheet theory of MacGinitie (1941) cannot be considered as a possible mechanism to explain the removal of particles in the 0.8 to $3.0 \mu$ range in our studies. According to this theory, when the animal is feeding, a mucous sheet that covers the entire gill surface intercepts all particles from the water passing through the gills. In all individual experiments we conducted, efficiency of removal was lower in the 1.0 to $3.0 \mu$ size range than at larger sizes. Existence of a mucous sheet should have resulted in complete retention of the smaller particles rather than in the partial retention observed. The plot for per cent removal vs. size would have then been a straight line showing equal efficiency of removal of particles of all sizes instead of the curve we obtained (Figs. 2 through 5 ).

Much controversy has evolved around the mucous sheet theory of MacGinitie (1941) as opposed to the straining function of the latero-frontal cilia. MacGinitie claimed that when the mucous sheet was absent from the gills of the four pelecypod species he studied, no feeding was taking place, in effect disregarding the involvement of ciliary mechanisms in particle retention.

Nelson (1960) objected to the mucous sheet theory on the basis that if a mucous net fine enough to trap bacteria were spread across the gills, it would be drawn down against the lateral cilia and into the ostia by the strong water currents pumped through the gills interfering with the function of both. Jørgensen (1966) stated that it is unlikely that the complicated sorting mechanisms of the bivalve gill should not play a part in their feeding process as would be the case if a mucous sheet was required. Owen (1966) expressed the same objection and added that such a continuous mucous sheet would be nearly impossible to maintain in the presence of the adjacent tracts of frontal cilia beating in opposite directions. Dral (1967) did not find any supporting evidence for existence of a mucous sheet in Mytilus edulis in heavy or dilute particle concentrations and pointed out that all observations indicated that the latero-frontal cilia constitute the filtration mechanism.

Jorgensen $(1955,1966)$ tried to conciliate the conflicting interpretations by suggesting that filtration by means of mucous sheets occurs in water that contains only small concentrations of suspended material and that in water with large particle concentrations, filtration is accomplished by ciliary mechanisms.

Our experiments covered a wide range of concentrations (Fig. 7). The curve for efficiency removal obtained in every experiment showed the same pattern described in the results. The presence of an inflection point in every instance, which has been given as an indication of the absence of a mucous sheet, suggests that particle retention was accomplished by a mechanism other than the mucous sheet at low as well as at high concentrations. Particle retention on the gills by latero-frontal cilia, however, is very probably enhanced by other responses such as muscular contraction of the gills and ostia, vascular enlargement of tissues around the ostia and secretion of mucus in a manner other than as a continuous sheet (Verwey, 1952; Owen, 1966).

The preceding discussion has considered particle filtration in terms of per cent removal since much of the previous work has been presented in this manner. From an ecological aspect, the data become more significant when presented in terms of volume. Although per cent removal was lower between 1.0 and $3.0 \mu$ for natural particles and 1.0 and $2.0 \mu$ for kaolinite than at larger sizes, volumes 
removed in these size ranges constituted the largest single fraction within the total size range investigated. This resulted from the smaller particles between 1.0 and $3.0 \mu$ being many times more numerous than those of larger size (Table I).

The oysters filtered relatively large quantities of solids in the 0.8 to $3.0 \mu$ size range. No effort was made in this study to differentiate between the fraction of the particles filtered out and ingested and that of particles filtered out but rejected as pseudofaeces. However, data collected in concurrent studies suggested that particles in this size range are the major component of solids ingested by oysters. Approximately $95 \%$ of the particles counted microscopically in dispersed samples of oyster faeces were smaller than $3 \mu$ (Haven and MoralesAlamo, 1966a). Eighty to ninety per cent by volume of the particles in similar samples were smaller than $4 \mu$ as determined with the Coulter Counter (Haven and Morales-Alamo, 1968).

These findings suggest that particles in this size range suspended in the water may play an important role in the nutrition of oysters and other lamellibranchs. A review of much of the existing information on size of particles suspended in coastal waters is given by J $\phi$ rgensen (1966). He concludes that in respect to the phytoplankton which are of importance in the nutrition of lamellibranchs, the nanno- and ultraplankton (less than $5.0 \mu$ ) mostly constitute the larger and often even the dominant part of the phytoplankton. Included in the size class are the marine bacteria which may range in size from less than $1 \mu$ up to about $2.5 \mu$.

Organic detritus has also been suggested as being an important food source for filter-feeding lamellibranchs (Verwey, 1952). Mullin (1965a) found that the 1-10 $\mu$ fraction of the particulate matter from 20 stations in the western Indian Ocean constituted on the average $58 \%$ of the total particulate organic carbon measured. Subsequently, Mullin (1965b) stated that phytoplankton carbon accounted for less than $20 \%$ of the total particulate carbon, making carbon in the form of detritus or heterotrophic organisms considerably more important than was suggested in his earlier report. Newell (1965) suggested that much of the food supply of filter feeders may be provided by microörganisms attached to fine size suspended organic and mineral particulate matter.

Removal of fine particles in the 1 to $10 \mu$ range by oysters and possibly by other filter feeders may also be an important factor in sedimentary processes affecting the physical and chemical characteristics of bottom substrates and the benthic communities they support (Haven and Morales-Alamo, 1966a, 1966b, 1968). In a similar manner, radionuclides adsorbed onto clay mineral particles or incorporated into bacterial and algal cells as a result of accidental contamination of an estuary may be removed from the water by the filtration activity of filter feeders and deposited on the bottom where their accumulation may become a hazard.

Appreciation is expressed to Mr. John Norcross, Dr. Joseph Loesch, and Mr. Frank Wojcik of the Virginia Institute of Marine Science for assistance in statistical analysis and in preparation of computer programs.

\section{SumMaRY}

1. Particle filtration by the oyster Crassostrea airginica was studied in the 1.0 to $12.0 \mu$ size range in relation to naturally occurring particles and to kaolinite suspensions in filtered river water. 
2. Oysters were held in troughs of flowing water under conditions similar to their natural environment. Particle number and volumes entering and leaving the troughs were enumerated using a Coulter electronic particle counter. Particle diameter was expressed as that of a sphere having a volume equal to the particle.

3. Results of the study were expressed as per cent of total particles removed in various size increments or in volumes removed over the same size range.

4. Oysters filtered naturally occurring particles in the 1.0 to $3.0 \mu$ range with about one-third the efficiency as larger particles. Above $3.0 \mu$ there was no change in efficiency with increasing particle size. For kaolinite particles, oysters removed particles in the 1.0 to $2.0 \mu$ range with about half the efficiency as larger particles. Above this size there was no change.

5. When results are expressed in terms of per cent removal, the importance of the small sized particles is minimized. In terms of volume, particles in the 1.0 to $3.0 \mu$ range constitute the largest single size fraction over the 1.0 to $12.0 \mu$ range.

6. The consistent presence of an inflection point at a particle size around 2.0 $3.0 \mu$ in the curve for per cent removed $v s$. particle size is an indication that the distance between adjacent latero-frontal cilia is the factor that determines the smallest particle size that can be completely retained by the oyster gill.

7. Presence of the inflection point is also interpreted as negating the existence of a mucous sheet over the gills, as suggested by MacGinitie (1941).

8. Particles in the 1.0 to $3.0 \mu$ range may play an important role in the nutrition of oysters and other lamellibranchs. Their removal by these organisms may also be an important factor in sedimentary processes.

\section{LITERATURE CITED}

Atkins, D., 1938. On the ciliary mechanisms and interrelationships of lamellibranchs. VII. Latero-frontal cilia of the gill filaments and their phylogenetic value. Quart. $J$. Microscop. Sci., $80: 346-430$.

Ballantine, D., and J. E. Morton, 1956. Filtering, feeding, and digestion in the lamellibranch Lasaea rubra. J. Mar. Biol. Ass. U. K., $35: 241-274$.

Chipman, W. A., and J. G. Hopkins, 1954. Water filtration by the bay scallop, Pecten irradians, as observed with the use of radioactive plankton. Biol. Bull., 107: 80-91.

DraL, A. D. G., 1967. The movements of the latero-frontal cilia and the mechanism of particle retention in the mussel. Netherlands J. Sea Res., $3: 391-422$.

Elsey, C. R., 1935. On the structure and function of the mantle and gill of Ostrea (Crassostrea) gigas and Ostrea lurida. Trans. Roy. Soc. Canada, 29: 131-160.

Galtsoff, P. S., 1928. Experimental study of the function of the oyster gills and its bearing on the problems of oyster culture and sanitary control of the oyster industry. Bull. Bur. Fish. U. S., 44 : 1-39.

Guenther, W. C., 1964. Analysis of Variance. Prentice-Hall, Englewood Cliffs, New Jersey, 199 pp.

Haven, D. S., and R. Morales-Alamo, 1966a. Aspects of biodeposition by oysters and other invertebrate filter feeders. Limnol. Oceanogr., 11 : 487-498.

Haven, D. S., and R. Morales-Alamo, 1966b. Use of fluorescent particles to trace oyster biodeposits in marine sediments. J. Cons. Perma. Int. Explor. Mer, $30: 267-269$.

Haven, D. S., and R. Morales-Alamo, 1968. Occurrence and transport of faecal pellets in suspension in a tidal estuary. Sediment. Geol., 2 : 141-151.

JøRGENSEN, C. B., 1949. The rate of feeding by Mytilus in different kinds of suspension. J. Mar. Biol. Ass. U. K., $28: 333-344$.

J $\varnothing$ RGENSEN, C. B., 1955. Quantitative aspects of filter feeding in invertebrates. Biol. Rev., 30 : 391-454. 
J фRGENSEN, C. B., 1960 . Efficiency of particle retention and rate of water transport in undisturbed lamellibranchs. J. Cons. Perma. Int. Explor. Mer, 26: 94-116.

Jørgensen, C. B., 1966. Biology of Suspension Feeding. Pergamon Press, New York, $357 \mathrm{pp}$.

J фrgensen, C. B., ANd E. D. Goldberg, 1953. Particle filtration in some ascidians and lamellibranchs. Biol. Bull., $105:$ : 477-489.

KubitscheK, H. E., 1960. Electronic measurement of particle size. Research, 13: 128-135. LoOSANOFF, V. L., 1958. Some aspects of behavior of oysters at different temperatures. Biol. Bull., 144 : 57-70.

Loosanoff, V. L., AND J. B. ENGLe, 1947. Effects of different concentrations of microorganisms on feeding of oysters (O. virginica). Bull. Bur. Fish. U. S., 51: 31-57.

MAcGinitie, G. E., 1941. On the method of feeding of four pelecypods. Biol. Bull., 80: 18-25.

Mullin, M. M., 1965a. Size fractionation of particulate organic carbon in the surface waters of the western Indian Ocean. Limnol. Oceanogr., 10:459-462.

Mullin, M. M., 1965b. Size fractionation of particulate organic carbon in the surface waters of the western Indian Ocean. Addendum. Limnol. Oceanogr., 10: 610-611.

Nelson, B. W., 1963. Removal of kraft effluent from river water by suspended sediment. Tappi, J. Tech. Ass. Pulp. Pap. Ind., $46: 277-284$.

Nelson, T. C., 1960. The feeding mechanism of the oyster. II. On the gills and palps of Ostrea, edulis, Crassostrea virginica, and C. angulata. J. Morphol., 107: 163-191.

Newell, R., 1965. The role of detritus in the nutrition of two marine deposit feeders, the prosobranch Hydrobia ulvae and the bivalve Macoma balthica. Proc. Zool. Soc. London, $144: 25-45$.

Owen, G., 1966. Feeding. Pages 1-51 in K. M. Wilbur and C. M. Yonge, Eds., Physiology of Mollusca. Academic Press, New York.

Sheldon, R. W., and T. R. Parsons, 1967. A Practical Manual on the Use of the Coulter Counter in Marine Science. Coulter Electronics, Ontario, $66 \mathrm{pp}$.

Sмiтh, R. J., 1958. Filtering efficiency of hard clams in mixed suspensions of radioactive phytoplankton. Proc. Nat. Shellfish. Ass., 48 : 115-124.

Snedecor, G. W., 1956. Statistical Methods. Iowa State College Press, Ames, Iowa, 534 pp.

TAMmes, P. M. L., AND A. D. G. Dral, 1955. Observations on the straining of suspensions by mussels. Arch. Neerl. Zool., 11: 87-112.

VERWEY, J., 1952. On the ecology of distribution of cockle and mussel in the Dutch Waddensea, their role in sedimentation and the source of their food supply. Arch. Neerl. Zool., 10: 172-239.

Willemsen, J., 1952. Quantities of water pumped by mussels (Mytilus edulis) and cockles (Cardium edule). Arch. Neerl. Zool., 10:153-160. 